\title{
C típusú distalis radius törések kezelése variábilis szögállású szögstabil lemezzel
}

\author{
DR. BITA LÁSZLÓ, DR. SZALAI ZOLTÁN, SZALAI SAROLTA
}

\section{ÖSSZEFOGLALÁS}

A szerzők ismertetik az AO 23 C1-3 (továbbiakban C) típusú distalis radius törések variábilis szögállású (VA) szögstabil lemezzel történő kezelését osztályukon 2011. január 1. és 2015. december 31. között. A statisztikai adatok bemutatását követően leírják az osztályukon bevált mútéti módszerüket. Eredményeiket és a betegek elégedettségét a DASH score alapján értékelték. Tapasztalataik alapján megállapították, hogy az azonnali mozgásstabil szintézist adó szögstabil lemezes szintéziseknél a variábilis szögállású lemezek alkalmazása további előnyöket ad az operatőr számára a C típusú distalis radius törések mútéti ellátásakor.

\section{Kulcsszavak: $\quad$ Radius törés; Csuklósérülés; Belsö rögzítés; Lemezelés;} Szögstabil implantátum; Töréskezelés;

L. Bita, Z. Szalai, S. Szalai: Variable angle LCP osteosynthesis of type C distal radius fractures

The authors present type $C$ distal radius fractures treated with variable angle LCP in their department between 01.01.2011 and 12.31.2015. After introducing statistical data, the operative technique is demonstrated. The results and patient satisfaction were evaluated using DASH score. The authors have determined benefits of using VA LCP in the treatment for type $\mathrm{C}$ distal radius fractures compared to normal LCP.

\section{Keywords: $\quad$ Bone plates; Fracture fixation, Internal - Instrumentation;} Radius fractures - Surgery; Wrist injuries - Surgery; 


\section{BEVEZETÉS}

Az ízületbe hatoló darabos distalis radius törések kezelése mindig is komoly kihívást jelentett a baleseti sebészek számára. Az átlagéletkor növekedésével és az ezzel járó osteoporosis fokozódásával emelkedik a törések száma, és ezzel párhuzamosan a töréstípusokon belül egyre nagyobb lesz a $C$ típusú törések számaránya. Természetesen ezek számára a konzervatív kezelés és a percutan tűzés Kirschner dróttal nem jelent ideális megoldást, nagy többségben mútéti beavatkozást igényelnek. Szögstabil lemezzel kezelt C típusú töréseknél figyelembe vettük a beteg korát, általános állapotát, kísérő betegségeit, együttműködési készségét. A szögstabil lemezek megjelenése nagy segítséget jelent e törések kezelésében. A lemezek népszerűsége nem véletlen, hiszen alkalmazásukkal a töréskezelés legmodernebb elvei érvényesülnek $(2,8,10-13,16)$.

Osztályunkon 2000-ben kezdtük alkalmazni a nem variábilis szögállású szögstabil radius lemezt (továbbiakban hagyományos radius szögstabil lemez). Az utóbbi évek fejlesztéseinek köszönhetően a cégek újabb és modernebb lemezeket állítanak elő. Megjelentek a variálható szögállású lemezek, amelyek tulajdonsága, hogy a lemez fejében levő furatokba behelyezendő poliaxialis csavarok az ideális behelyezési szögtől szükség szerint +/- 15-15 fokkal megdöntve helyezhetők be, így biztosítva a törtdarabok még biztonságosabb rögzítését $(13,14,16)$ (1. ábra).

2010-ben kezdtük alkalmazni elsősorban C típusú töréseknél a Volar Column Distal Radius plate-t (továbbiakban VCP), illetve a Two Column Distal Radius plate-t (továbbiakban TCP), majd ezt követően egy évvel később bevezetésre került osztályunkon a Vortex distalis radius lemez (továbbiakban Vortex). Közleményünkben e lemezekkel szerzett tapasztalatainkról, illetve eredményeinkről kívánunk beszámolni.

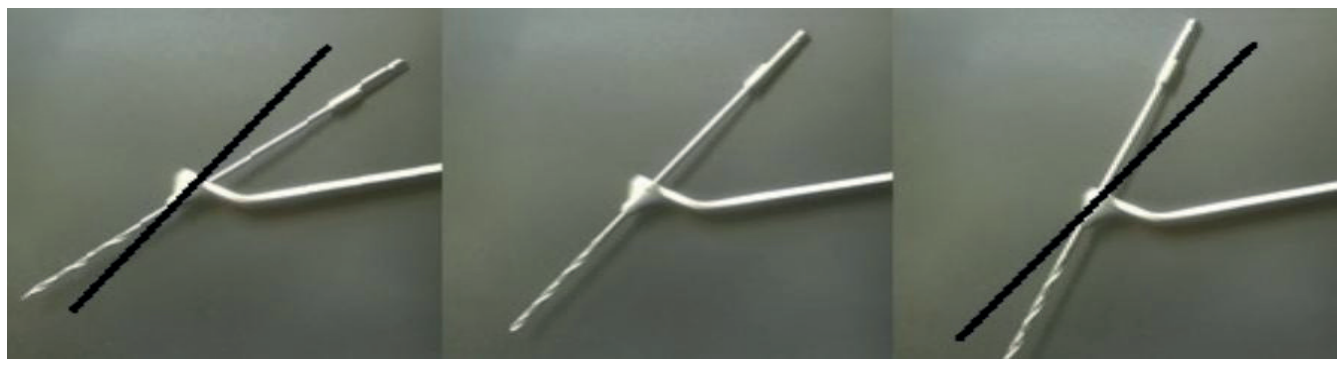

1. ábra A variábilis szögállás modellezése

\section{ANYAG ÉS MÓDSZER}

2011. január 1. és 2015. december 31. között (5 év) alatt 122718 év feletti, típusos radius törést elszenvedett sérültet láttunk el kórházunkban, ebből 688 esetben (56\%) alkalmaztunk mútéti kezelést. Ezek évenkénti lebontását tartalmazza az l. táblázat.

A 688 mútéti úton kezelt radius törést $A O$ szerint osztályoztuk, amelyeket évenkénti lebontásban a II. táblázat mutatja be.

2011 és 2015 között osztályunkon 355 C típusú törést kezeltünk mútéti úton. Öt esetben fixateur externe-nel rögzítettük a törést, a többi esetben szögstabil radius lemezt alkalmaztunk. Az 5 fixateur externe-nel operált betegnél négy esetben III. fokban nyílt törés, egy esetben a rendkívül kis distalis törtvég miatt választottuk ezt a megoldást. A C típusú törések éves megoszlását a III. táblázat mutatja.

2010 év elején kezdtük el alkalmazni a VCP-t C típusú töréseknél, majd 2010 szeptemberétől vezettük be a variábilis szögállású TCP-t szintén $C$ típusú töréseknél. A mútéti beavatkozások évek szerinti megoszlását a IV. táblázatban tüntettük fel.

Vizsgáltuk a $C$ típusú törések kezelésének megoszlását TCP és a Vortex lemez között, amelyet az $V$. táblázat mutat be.

A nemek szerinti megoszlást, az átlagéletkort, és a nemekre levetített átlagéletkort a VI. táblázat tünteti fel.

Külön megnéztük a mútéten átesett betegek átlagéletkorát a TCP és Vortex lemez vonatkozásában, amelyet a VII. táblázatban szemléltetünk. 
Megvizsgáltuk a férfiak és nők arányát | eredményét a VIII. táblázatban mutatjuk be. e két lemezzel végzett mútéteinknél. Ennek

I. táblázat 1227 törés konzervativ és mütéti kezelésének megoszlása évenkénti lebontásban

\begin{tabular}{|c|c|c|c|}
\hline Év & Ambuláns kezelés & Mútéti kezelés & Százalék \\
\hline 2011 & 275 & 149 & $54 \%$ \\
\hline 2012 & 208 & 127 & $61 \%$ \\
\hline 2013 & 212 & 123 & $58 \%$ \\
\hline 2014 & 273 & 133 & $51 \%$ \\
\hline 2015 & 259 & 151 & $58 \%$ \\
\hline Összes & $\mathbf{1 2 2 7}$ & $\mathbf{6 8 8}$ & $\mathbf{5 6 \%}$ \\
\hline
\end{tabular}

II. táblázat 688 mütéti úton kezelt típusos radius törés $A O$ osztályozás szerinti megoszlása évenkénti lebontásban

\begin{tabular}{|c|c|c|c|c|c|}
\hline Év & Törés típus & A & B & C & Összes \\
\hline 2011 & 67 & 7 & 75 & 149 \\
\hline 2012 & 53 & 6 & 68 & 127 \\
\hline 2013 & 54 & 6 & 63 & 123 \\
\hline 2014 & 64 & 4 & 70 & 138 \\
\hline 2015 & 66 & 6 & 79 & 151 \\
\hline Összes & $\mathbf{3 0 4}$ & $\mathbf{2 9}$ & $\mathbf{3 5 5}$ & $\mathbf{6 8 8}$ \\
\hline
\end{tabular}

\section{III. táblázat A C típusú törések megoszlása évenként}

\begin{tabular}{|l|l|l|l|l|l|}
\hline Év & Törés típus & C1 & C2 & C3 & Összes \\
\hline 2011 & 29 & 33 & 13 & 75 \\
\hline 2012 & 27 & 29 & 12 & 68 \\
\hline 2013 & 31 & 18 & 14 & 63 \\
\hline 2014 & 28 & 26 & 16 & 70 \\
\hline 2015 & 38 & 24 & 17 & 79 \\
\hline Összes & $\mathbf{1 5 3}$ & $\mathbf{1 3 0}$ & $\mathbf{7 2}$ & $\mathbf{3 5 5}$ \\
\hline
\end{tabular}


IV. táblázat A C típusú törések mütéti beavatkozás szerinti felosztása évenkénti lebontásban.

\begin{tabular}{|c|c|c|c|c|c|c|c|}
\hline Év & $\begin{array}{l}\text { Mútét } \\
\text { típusa }\end{array}$ & VCP & TCP & Vortex & $\begin{array}{l}\text { Fixateur } \\
\text { externe }\end{array}$ & $\begin{array}{c}\text { Hagyományos } \\
\text { lemez }\end{array}$ & Összes \\
\hline \multicolumn{2}{|c|}{2011} & 6 & 30 & 5 & 1 & 33 & 75 \\
\hline \multicolumn{2}{|c|}{2012} & 2 & 17 & 48 & 1 & ---- & 68 \\
\hline \multicolumn{2}{|c|}{2013} & ---- & 19 & 44 & ---- & ---- & 63 \\
\hline \multicolumn{2}{|c|}{2014} & ---- & 38 & 31 & 1 & ---- & 70 \\
\hline \multicolumn{2}{|c|}{2015} & ---- & 51 & 26 & 2 & ---- & 79 \\
\hline \multicolumn{2}{|c|}{ Összes } & 8 & 155 & 154 & 5 & 33 & 355 \\
\hline
\end{tabular}

V. táblázat C típusú törések kezelésének megoszlása A TCP és a Vortex lemez között.

\begin{tabular}{|c|c|c|c|c|}
\hline Törés típusa & Mútét típusa & TCP & Vortex & Összes \\
\hline C1 & 58 & 61 & 119 \\
\hline C2 & 59 & 64 & 123 \\
\hline C3 & 38 & 29 & 67 \\
\hline Összes & $\mathbf{1 5 5}$ & $\mathbf{1 5 4}$ & $\mathbf{3 0 9}$ \\
\hline
\end{tabular}

VI. táblázat A mütéti úton kezelt betegek átlag életkora és a nemek közötti megoszlása.

\begin{tabular}{|c|c|c|}
\hline Nemek & Átlagéletkor 62,3 év & Százalékos megoszlás \\
\hline Férfi & 55,4 & $28 \%$ \\
\hline Nö & 64,6 & $72 \%$ \\
\hline
\end{tabular}

\section{VII. táblázat A mütéten átesett betegek átlagéletkora TCP és Vortex lemez} vonatkozásában.

\begin{tabular}{|c|c|}
\hline TCP-vel végzett mútétek esetében & 55,1 \\
\hline Vortex lemezzel végzett mútétek esetében & 68,4 \\
\hline
\end{tabular}

VIII. táblázat Férfiak és nők aránya TCP és Vortex lemeznél

\begin{tabular}{|c|c|c|}
\hline & TCP & Vortex \\
\hline Férfi & 58 & 33 \\
\hline Nő & 97 & 121 \\
\hline Összes & 155 & 154 \\
\hline
\end{tabular}

\section{MÜTÉTI TECHNIKA}

A radius törések szögstabil lemezzel történő kezelésénél a volaris Henry-féle feltárást alkalmazzuk. A distalis radiovoláris bőrmetszést követően a musculus flexor carpi radialis ina mellett hatolunk be, a musculus pronator quadratust élesen hosszanti irányba behasítjuk $(3,6,12,16)(2-3$. ábrák).
Osztályunkon bevált módszer szerint az operatőrt két asszisztens segíti a minél jobb repozíció elérésében és megtartásában. Törekszünk az ízfelszín anatómiai helyreállítására, és ha szükség van, a törtdarabokat ideiglenesen Kirschner dróttal rögzítjük. Kiválasztjuk az ideális lemezt, a radius voláris felszínére helyezzük, ezt képerősítővel ellenőrizzük. A lemez ovális lyukába corticalis csavart helyezünk. 
Ismételten ellenőrizzük a lemez helyzetét és amennyiben szükséges a kívánt korrekció még elvégezhető $(8,9,11,12,15-17)$.

A lemez fejének variábilis szögállású distalis furataiba legalább három szögstabil csavart helyezünk be. A dorsalis kitört részt a lemez fejének proximalis furatsorából, megfelelő szögben megdöntve bevezetett csavarral rögzítjük. A lemez szárába a corticalis csavar mellé a törés típusától függően még legalább két darab szögstabil csavart helyezünk be. A csavarok helyzetét és hosszát képerősítővel ellenőrizzük, a csavarok nem érhetnek be az ízületbe és a szemközti corticalison túl (4. ábra).

A csavarok ellenőrzésénél gondolni kell arra, hogy a radius dorsalis ízfelszíne nem sima (Lister tuberculum!), valamint arra, hogy a radius distalis ízfelszíne az alkar hossztengelyére radiál felé körülbelül 25-30 fokos szöget zár be, ezért a csuklót 20-25 fokban, oldalirányban megemelve, ellenőrizhetjük a csavarok hosszát és helyzetét $(3,4,8,11,12$, $14,16)$.

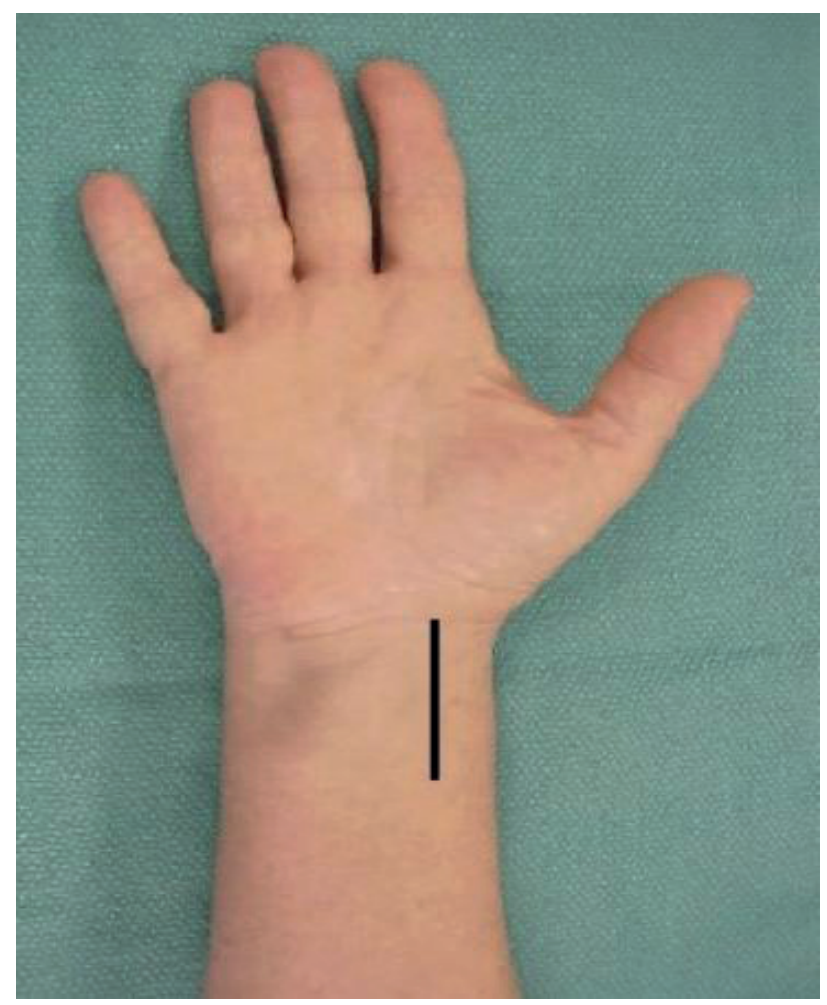

2. ábra A típusos mütéti feltárás

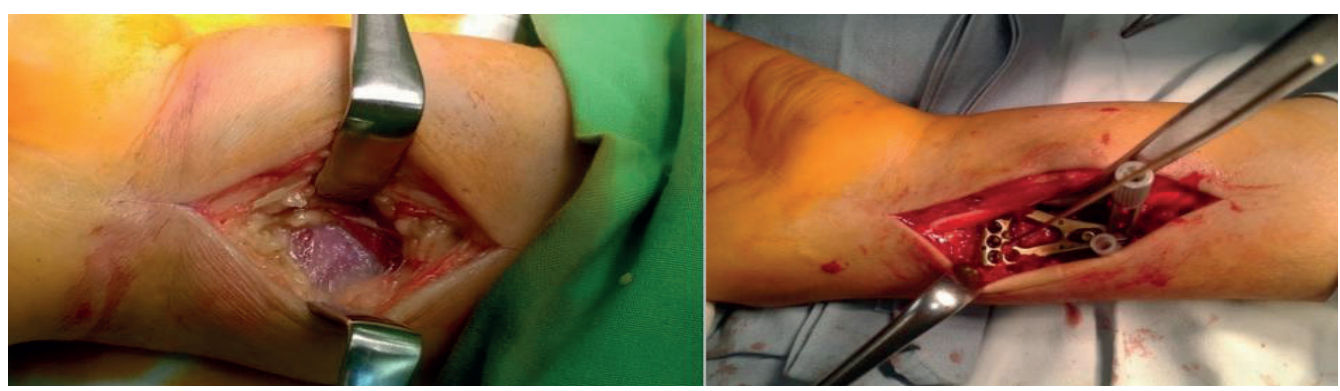

3. ábra Intraoperativ képek, a feltárás 

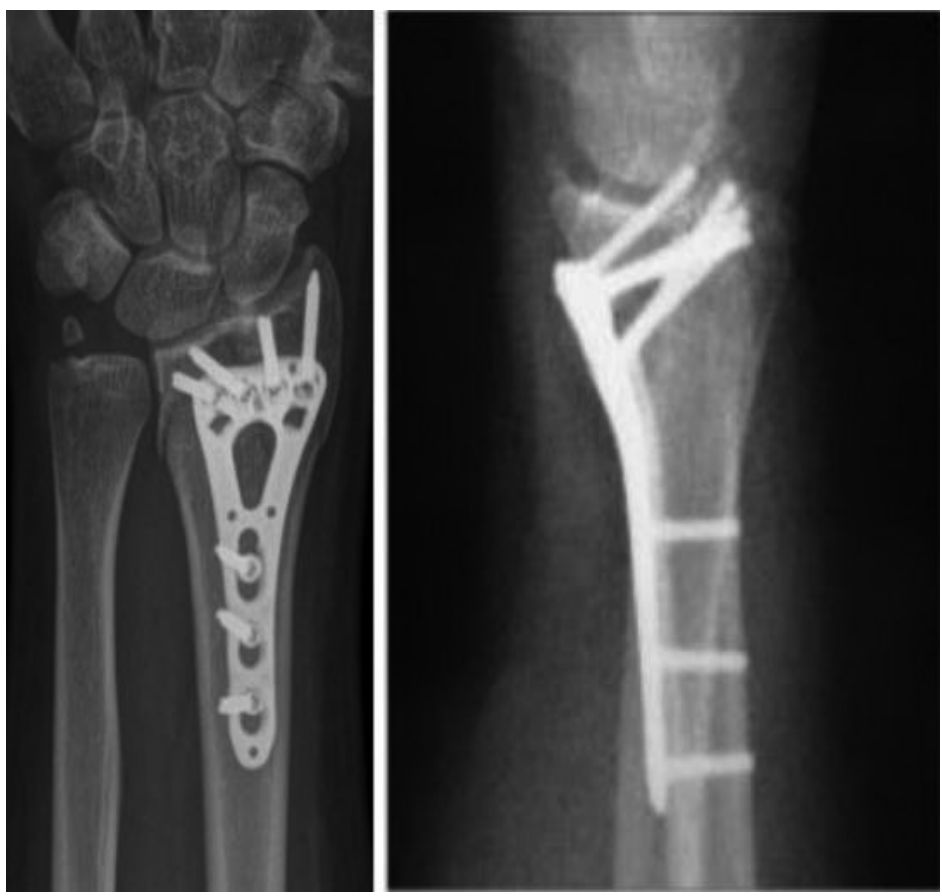

4. ábra A csavarok optimális helyzete röntgenfelvételen két eset kapcsán

\section{További kezelés}

1. nap: Mútét, gipszrögzítés (?)

2. nap: Kötés, röntgenkontroll

3. nap: Emisszió, torna elkezdése

8-10. nap: Varratszedés, gipszlevétel, a torna folytatása

3 hónapig havonta ellenőrzés (röntgen, funkció)

6 hónapig szükség szerinti ellenőrzés (röntgen, torna)

Fémkivétel nem ajánlott, amennyiben a betegnek panaszt okoz, és a beteg kéri a 6. és 12 . hónap között elvégezzük.

\section{Kell-e a mütét után gipszet felhelyezni?}

Ahogy hangsúlyoztuk, mozgásstabil osteosynthesisről van szó. Viszont osztályunkon varratszedésig a beteg toleranciájától, a lágyrészek állapotától, ödémájától függően az esetek háromnegyed részében gipszet helyezünk fel.

\section{EREDMÉNYEK}

2013-tól a zárt C típusú distalis radius töréseknél már csak a VA szögstabil lemezeket használtuk, öt esetben alkalmaztunk fixateur externe rögzítést. TCP-t, illetve a Vortex lemezt közel ugyanannyi esetben használtuk, adódik a kérdés, melyik lemez alkalmazásánál értünk el jobb eredményt?

A hathónapos utánkövetés eredményeit a módosított DASH-score alapján értékeltük.

- A betegek egy kérdőívet kaptak, amely 30 kérdést tartalmazott. Különböző tevékenységek végzésére, fizikai aktivitásra, fájdalomra, zsibbadásra, ízületi merevségre, elégedettségre kérdeztünk rá.

- A válaszokat a betegek 1-5 pontos skálán jelölték be.

- Az 1 pont a tünetmentességet, a nehézség nélkül végzett tevékenységet, míg az 5 pontos válasz a súlyos tüneteket, illetve a tevékenység elvégzésének képtelenségét jelzi.

A DASH indexet kiszámoltuk és ez alapján értékeltük az eredményeket. A 0 pontos DASH index a legjobb, míg a 100 pontos DASH index a legrosszabb eredményt tükrözi $(11,12,13$, 16). A TCP-vel végzett mútétek után a DASH score 23,4, míg a Vortex lemezzel végzett mútétek eredménye DASH score alapján 24,95, tehát szignifikáns különbség nem észlelhető. Eredményeink a nemzetközi eredményekkel 
összehasonlítva sem a mozgásterjedelem, sem a DASH score tekintetében nem mutatnak jelentős különbséget vagy eltérést $(1,5)$. Ez alapján megállapíthatjuk, hogy a két lemez használata során hasonló eredményeket értünk el, mindkettő jó effektivitással használható.

Korábban már feldolgoztuk és értékeltük a C típusú töréseknek az úgynevezett hagyományos szögstabil lemezzel és a Kirschner drótos, illetve fixateur externe-nel kezelt törések eredményeit. A hagyományos szögstabil lemez esetében a DASH score 28,5 volt, tehát a VA lemezek esetén egyértelmúen jobb eredményt értünk el $(9,10-14,16)$.

\section{Hibák és szövődmények}

A mútét során elkövetett hibáink a következők voltak:

- $2 \mathrm{~mm}$ vagy annál nagyobb lépcsőképződés az ízfelszínen: 7,8\%

- Dislocatio ad axim: $2,2 \%$

- Radius megrövidülése (5 mm): 3,5\%

\section{Szövődményeink}

- Felületes infekció: 5 eset

- Mély infekció: 1 eset

- Redislocatio: 11 eset

- Csavarlazulás: 5 eset

- CTS: 4 eset

- Ínsérülés: 2 eset

- Algodistrophia: 6 eset

A csukló mozgásokat 1, 3, 6 hónap után ellenőriztük, ezek eredményét mutatja a $I X$. táblázat. A funkció értékelése szintén a fentebb tett megállapításunkat támasztja alá.

\section{ESETBEMUTATÁS}

60 éves nőbeteg az utcán elesett, bal oldali I. fokban nyílt C3 típusú distalis radius törést szenvedett (5. ábra). Akutan mútétet végeztünk, TCP lemezzel rögzítettük a törést. Tekintettel a nyílt törésre a varratszedésig gipszsínrögzítést helyeztünk fel (6. ábra). Gyógytornát kezdtünk. Három hónappal a mútét után funkcionális felvételeket készítettünk (7-9. ábrák).

IX. táblázat A TCP és Vortex lemezzel operált betegeink funkcionális eredménye. Flexio - Extensio 1-3-6 hónapos korban

\begin{tabular}{|c|c|c|c|c|c|c|c|}
\hline Idő & \multicolumn{2}{|c|}{1 hónap } & \multicolumn{2}{c|}{ 3 hónap } & \multicolumn{2}{|c|}{6 hónap } \\
\hline Lemez & Flexio & Extensio & Flexio & Extensio & Flexio & Extensio \\
\hline TCP & 30 & 40 & 50 & 65 & 70 & 70 \\
\hline Vortex & 25 & 30 & 45 & 60 & 65 & 70 \\
\hline
\end{tabular}

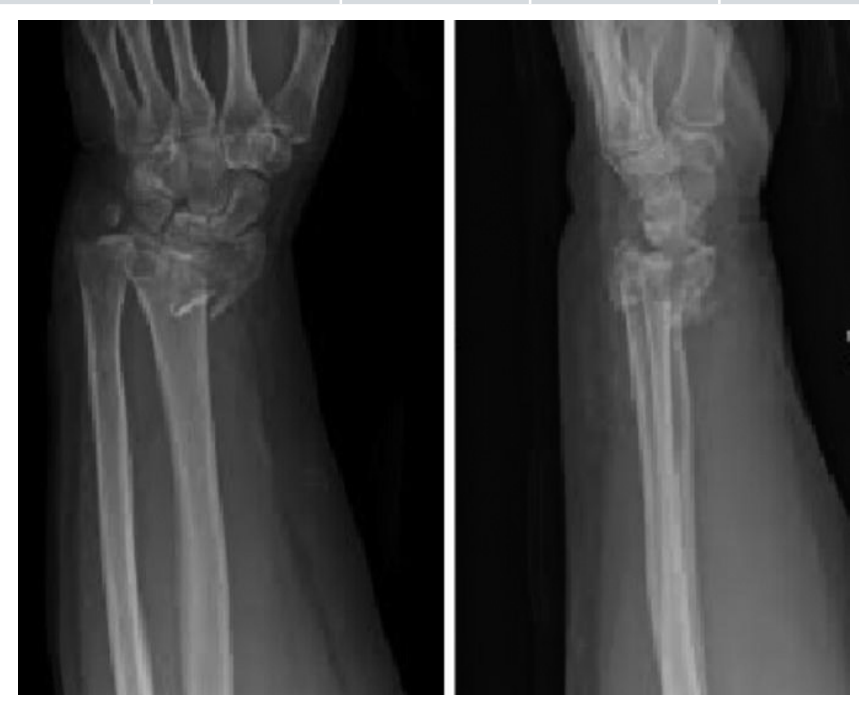

5. ábra 60 éves nöbeteg bal oldali C3 típusú radius törése 

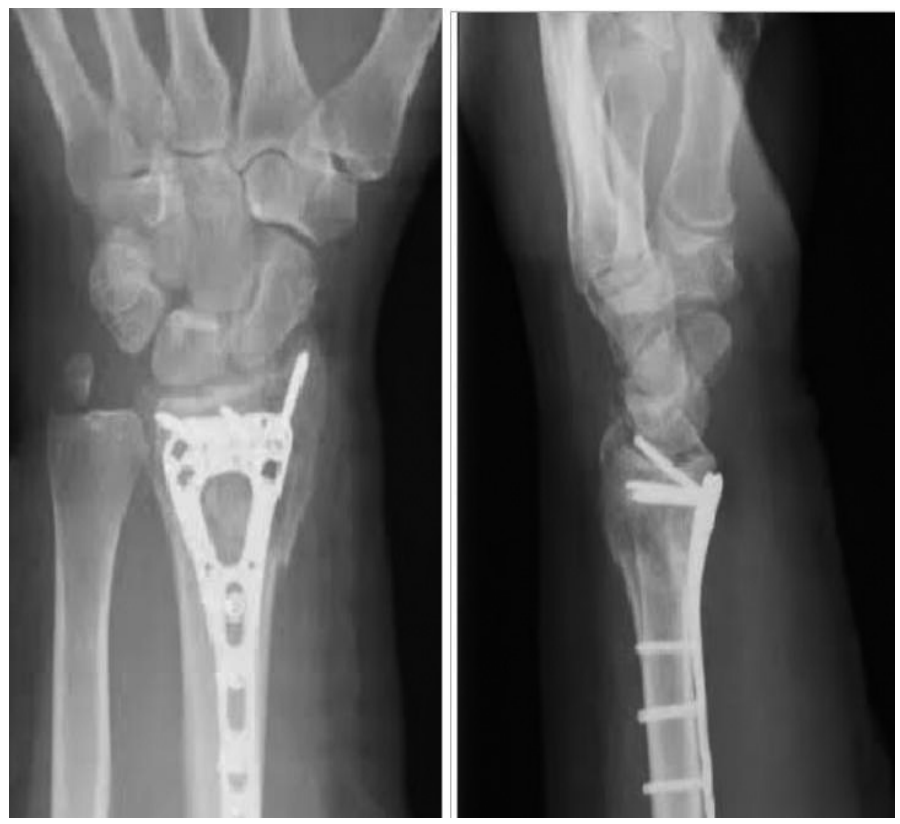

6. ábra A varratszedés és a gipszlevétel után készült posztoperativ röntgenfelvételek

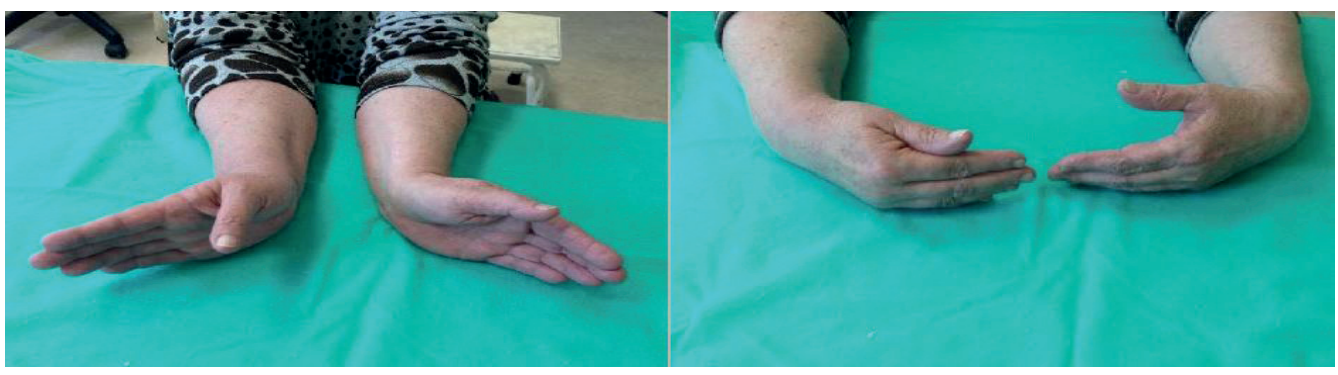

7. ábra Összehasonlító funkcionális felvétel mind két csuklóról 3 hónapos korban: flexio-extensio

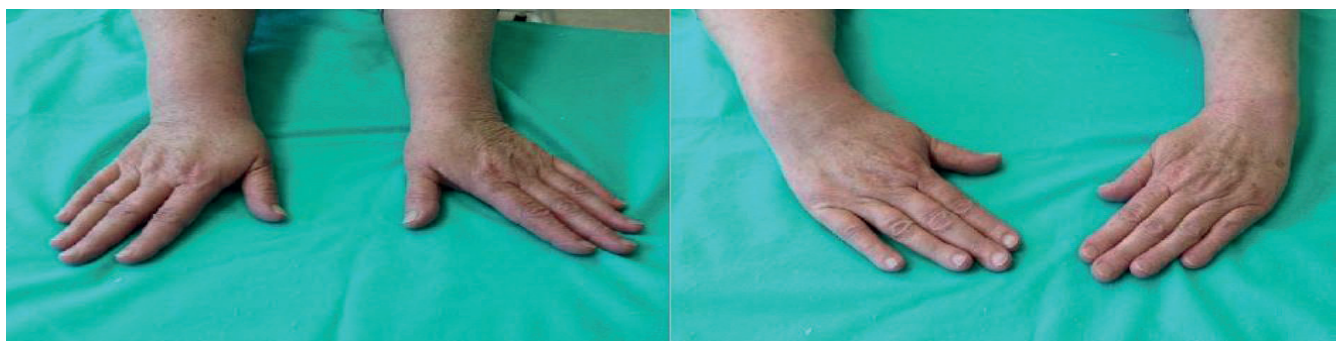

8. ábra Ulnar radialductio 


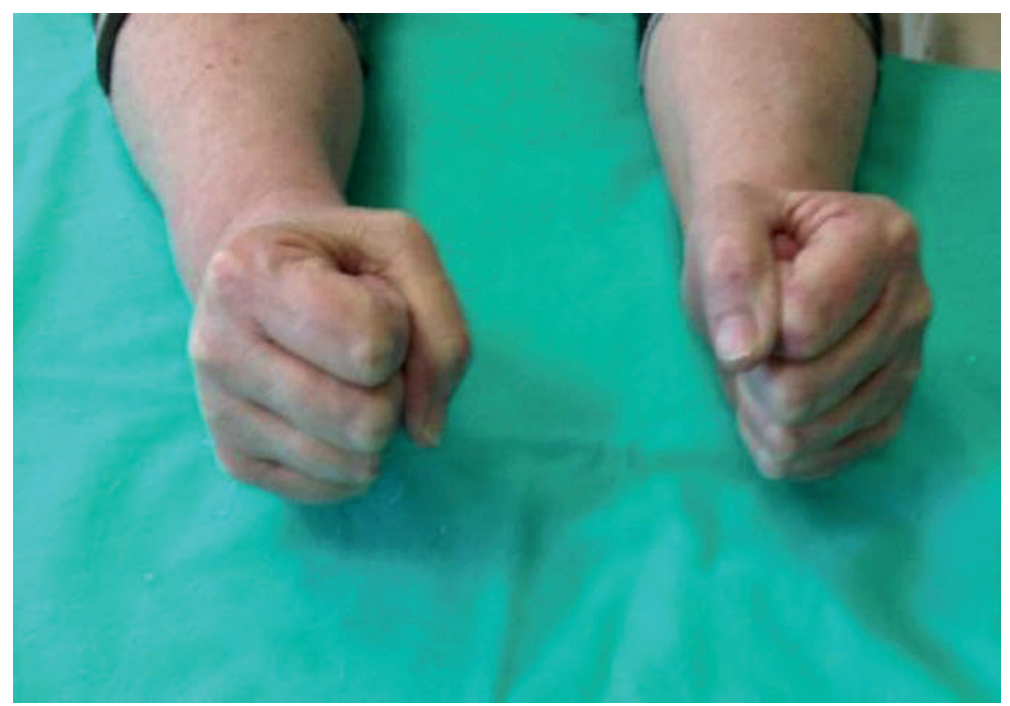

9. ábra Ujjmozgások összehasonlítása

\section{MEGBESZÉLÉS}

A C típusú distalis radius törések puzzle-hoz hasonlíthatók, amelynek több, egymással öszszekapcsolódó darabja van. Ezekből egy teherviselő egységet hozunk létre, amelyhez a tört darabokat hozzáadjuk és így egységes komplexet (szerkezetet) alkotunk. A tört fragmentumokat egyesítve azok, mint egy kalapács nyelébe illeszkednek bele a radius metaphysisébe. Törekednünk kell az ízfelszín anatómiai helyreállítására és a törtdarabok minél stabilabb rögzítésére. A volarisan felhelyezhető szögstabil lemezek mindezen elvárásoknak megfelelnek, éppen ezért előnyeit kihasználva jó eredménynyel alkalmazhatók $(6,8,11,12,14,16)$.

\section{Előnyei}

- Szöglettartó

- Kiterjeszthető az indikáció (C 1-2-3)
- Idősebb korosztályra is alkalmazható

- Egyszerű mútéti feltárás

- Jó stabilitást biztosítanak

- Alacsony a szövődmény ráta

- Korai funkcionális kezelés következtében aktív korban hamarabb munkaképes a sérült

Miért használjunk VA-t a fix szögállású megoldás helyett?

- Könnyebb a lemez pozicionálása

- Könnyebben elkerülhető, hogy a csavar esetleg az ízületbe kerüljön

- A kisebb tört darabokat könnyebben rögzíthetjük

A mútéti szám és az eredményeink alapján azt a következtetést vonhatjuk le, hogy a C típusú radius törések kezelésére a variábilis szögállású radius lemezek alkalmasabbak a fix szögállású lemezeknél (14). 


\section{IRODALOM}

1. Anakwe R., Khan L., Cook R., McEachan J.: Locked volar plating for complex distal radius fractures: Patient reported outcomes and satisfaction. J. Orthop. Surg. Res. 2010. 5: 51. https://doi.org/10.1186/1749-799X-5-51

2. Andersen G. R., Rasmussen J., Dahl B., Solgaard S.: Older's classification of Colles fractures. Good intraobserver and interobserver reproducibility in 185 cases. Acta Orthop. Scand. 1991. 62: 463-464. https://doi.org/10.3109/17453679108996645

3. Axelrod T. S., McMurtry R.Y.: Open reduction and internal fixation of comminuted intraarticular fractures of the distal radius. J. Hand Surg. 1990. 15-A: 1-11. https://doi.org/10.1016/s0363-5023(09)91097-8

4. Dóczi J., Tasnádi L., Soltay P., Kádas I.: A konzervativan kezelt radius distalis vég-törések instabilitásának és rediszlokációjának összefüggései. Magyar Traumatológia Ortopédia Kézsebészet Plasztikai Sebészet, 1994. 37. (1): 47-51.

5. Egol K. A., Karia R., Zingman A., Lee S., Paksima N.: Hand stiffness following distal radius fractures Who gets it and is it a functional problem? Bull. Hosp. Jt. Dis. 2014. 72. (4): 288-293.

6. Felderhoff J., Wiemer P., Dronsella J., Weber U.: Operative Versorgung der distalen, instabilen Radiusfraktur mit der dorsalen/ palmaren Abstützplatte. Orthopäde, 1999. 28: 853-863. https://doi.ora/10.1007/s001320050475

7. Fernandez D. L., Geissler W. B.: Treatment of displaced articular fractures of the radius. J. Hand Surg. 1991. 16-A: 375-384. https://doi.org/10.1016/0363-5023(91)90001-R

8. Fitoussi F., Chow S. P.: Treatment of displaced intra-articular fractures of the distal end of the radius with plates. J. Bone Joint Surg. 1997. 79-A: 1303-1312. https://doi.orq/10.2106/00004623-199709000-00004

9. Glowacki K. A., Weiss A. P. C., Akelman E.: Distal radius fractures: concepts and complications. Orthopaedics, 1996. 19: 601-608.

10. Gordán F., Tóth K.: Rediszlokációra hajlamos radius distalis vég törés fedett Kirschner drótos tüzésének eredményei. Magyar Traumatológia Ortopédia Kézsebészet Plasztikai Sebészet, 1994. 37: 99-104.

11. Laky R.: Distalis radiustörések kezelése palmaris szegletstabil lemezes rögzítéssel. Magyar Traumatológia Ortopédia Kézsebészet Plasztikai Sebészet, 2003. 46. (3): 244-252.

12. Laky R.: The treatment of distal radius fractures with angle stable plate of the palmar side. Magyar Traumatológia Ortopédia Kézsebészet Plasztikai Sebészet, 2004. 47. Suppl. 2. 285.

13. Laky R.: The use of Herbert screws and wires or plates in the treatment of distal radius fractures. Scandinavian-Hungarian Congress of Hand Society Meeting. Kuopio Finnland. 2000. 16-19. August.

14. Rausch S., Hoffmeier K., Gueorguiev B. G., Klos K., Gras F., Hofmann G. O., Mückley T.: Vergleichende Studie zur statischen Festigkeit unterschiedlicher Verblockungsmechanismen multidirektional winkelstabiler Verriegelungen distaler Radiusplatten. Z. Orthop. Unfall. 2011. 149: 694-698. https://doi.orq/10.1055/s-0031-1280123

15. Rikli D. A., Regazzoni P.: Fractures of the distal end of the radius treated by internal fixation and early function. J. Bone Joint Surg. Br. 1996. 78-B: 588-592.

16. Szalai Z., Magyar L., Bita L., Kovács K.: Szemléletváltás a típusos radiustörések kezelésében osztályunkon a XXI. században. Magyar Traumatológia Ortopédia Kézsebészet Plasztikai Sebészet, 2013. 56. 4: 285-290.

17. Turchányi B., Cziffer E.: Háromdimenziós ligamentotaxis alkalmazása distal radiustörések helyreállításában. Magyar Traumatológia Ortopédia Kézsebészet Plasztikai Sebészet, 1996. 39: 383-389.

\section{Dr. Bita László}

Zala Megyei Szent Rafael Kórház, Traumatológiai Osztály

8900. Zalaegerszeg, Zrínyi u. 1. 